\title{
IMPACT OF CUSTOMER COMMITMENT IN SOCIAL MEDIA MARKETING ON PURCHASE DECISION - AN EMPIRICAL EXAMINATION
}

Shantharam B. B

M.Phil. Research Scholar, Department of Commerce, VELS Institute of Science, Technology \& Advanced Studies (VISTAS), Chennai, Tamil Nadu, India

\section{*P. Balaji}

Assistant Professor, Department of Commerce, Guru Nanak College (Autonomous), Chennai, Tamil Nadu, India

\section{Dr. P. Jagadeesan}

Professor and Head, Department of Commerce, VELS Institute of Science, Technology \& Advanced Studies (VISTAS), Chennai, Tamil Nadu, India

* Corresponding Author

\begin{abstract}
This primary study was aimed to investigate the consumer's commitment on purchase decision among social media users. The researcher was adopted survey method for the purpose of data collection. The data collected were subjected to data analysis using PSPP version Software, which is alternative for same. The result indicates only two factors are extracted out of customer commitment variables. Further, the result indicates that information and experience are the major key dimensions for the purpose of social media evaluation. To conclude, Experience Factor and Information Factor are significantly and positively influencing the purchase decision. Therefore, higher is the customer commitment in social media, higher is the purchase decision
\end{abstract}

Key Words: Customer Commitment, Purchase Decision, Social Media Marketing, Experience and Information

Cite this Article: Shantharam B. B, P. Balaji and Dr. P. Jagadeesan, Impact of Customer Commitment in Social Media Marketing on Purchase Decision - an Empirical Examination, Journal of Management, 6 (2), 2019, pp. 320-326.

http://www.iaeme.com/JOM/issues.asp?JType=JOM\&VType=6\&IType=2

\section{INTRODUCTION}

Social media acts as platform to share and discuss the opinion of the individuals. Social media facilitates to share ideas, messages, information, ideas, images and videos through particular 
social media networking sites. The mode of communication was changed due to the evolution of social media networking sites in the twenty first century (Yazdanifard., \& et al., 2011). Growth of the internet in developing countries helps for the usage of digital media to drove different opportunities in the global market (Norris, 2001; Donner, 2008). The way business firms think to make correspondence with consumers are rapidly changing in today's dynamic environment (Kaplan \& et al., 2001; Teece \& et al., 1997, Bharadwaj \& et al., 2013). Social media networking sites are mostly preferred my many people across the globe. Especially, in India there are 226 million social media networking sites users are available and it was predicted that after 2020 it will reach 250 million (Das \& Sahoo, 2011; Tidd \& Bessant, 2018). Social media is the fastest online tool to reach the consumer in hyper competitive environment and they also became their part of life (Dey \& et al., 2011; Chakravarthy, 1997; Chen \& et al., 2012; Rheingold, 2008). Social media are generally used to circulate the information for the purpose of creating awareness and education among the consumers with respect to products availability, new product development and introduction, brands, services and issues (Keller \& et al., 2011; Kotler, 2009; Ha, 2002). Social media facilitates participation, openness, conversation, community and connectedness (Constantinides and Fountain, 2008; Chan-Olmsted and et al., 2013; Munro \& Richards, 2011). According to statistica, the social media users are 2.5 billion in 2018 and estimated to reach three million at the end of 2019. On an average, across the globe internet users spend around 101.4 minutes per day. Consumers use social media to view the reviews and comments of the earlier users or consumers.

\section{REVIEW OF LITERATURE}

Alicia Mas-Tur and et al., (2016) conducted an empirical study to examine the role of family traits among adolescents those who use social media. The researchers made an attempt to explore valuable insights to devise appropriate marketing strategies to target potential consumers. The result indicates that active communication with consumers helped to capitalize the opportunities to enrich customer relationship management. Further, qualitative comparative analysis proves that social media sites are creating more interest and demand among the adolescents.

Christy Ashley and Tracy Tuten (2015) carried content analysis to devise innovative strategies and tactics for effective social media marketing. The researcher has adopted exploratory research method to explore branded social content and consumer engagement by selecting few top brand samples. This study primary aims to explore opportunities inherent in social media to create brand development and commitment among its users. The researchers found that integrated content, interactivity, functional appeal, emotional appeal, experiential appeal, unique selling proposition, comparative, resonance, user image, social cause, exclusivity, animation, sales promotions and user-generated content are the major dimensions and factors contributing for the success of social media marketing for brand development and consumer engagement.

Evan Cleave and et al., (2016) conducted an empirical investigation to examine the place marketing and branding through social media to explore the perception of municipal practitioners. This study primarily aims to explore the usage of social media as a promotional tool for the purpose of economic development of municipal. The researcher made an attempt to gather primary data from sixteen municipal development practitioners of Canada. The researcher found that social media helps to promote local services and political information rather than the brand position and they also provided various insights to use social media for better understanding of municipalities application for place marketing and place marketing. 
Impact of Customer Commitment in Social Media Marketing on Purchase Decision - an Empirical Examination

\section{OBJECTIVES OF THE STUDY}

1. To study the personal and social media usage profile of the employed youth.

2. To identify the underlying dominant dimensions of the customer commitment in Social Media marketing.

3. To explore the influence of customer commitment in social media marketing on purchase decisions.

\section{RESEARCH METHODOLOGY}

Primary data were collected through well designed and structured questionnaire from 116 private company employees residing in Chennai using non probability Convenient (or) Accidental sampling technique. The Customer commitment in social media variables and purchase decision variables were measured by using appropriate 5-point Likert scale. To check the consistency and reliability the scale, Cronbach's Alpha reliability criterion was employed. The result indicates that the Cronbach's Alpha reliability coefficient was 0.876 , which supports that the scale is more consistent and highly reliable.

\subsection{Questionnaire Design}

The questionnaire has been divided into 3 sections.

Section 1 deals with personal profiles and Social media usage profiles such as Gender, Marital status, Educational qualification, Occupational status, Nature of family, Monthly family income, Age, No. of years using Social media and Hours spent on social media per day. This section consists of nominal and interval scales.

Section 2 deals with 10 variables related to customer commitment in social media commitment among respondents.

Section 3 deals with 10 variables related to purchase decision among respondents.

\subsection{Application of Statistical Tools}

The primary data gathered through structured questionnaire were subjected to statistical analysis using PSPP Version 1.0.1 and statistical tools such as percentage analysis, descriptive statistics, factor analysis and multiple regression analysis has been applied to draw meaningful answers to research objectives of the study.

\section{ANALYSIS AND INTERPRETATION}

Table 1 Personal and Social Media Usage Profile of the Employed Youth

\begin{tabular}{|c|c|c|}
\hline $\begin{array}{c}\text { Employee's Demographic Characteristics (N = 116) } \\
\text { Gender }\end{array}$ & Frequency & Percent \\
\hline Female & 54 & 46.6 \\
\hline Male & 62 & 53.4 \\
\hline Educational Qualification & 13 & 11.2 \\
\hline UG & 73 & 62.9 \\
\hline PG Professional Nature of Family & 30 & 25.9 \\
\hline Nuclear / Small Family & 86 & 74.1 \\
\hline
\end{tabular}


Shantharam B. B, P. Balaji and Dr. P. Jagadeesan

\begin{tabular}{|c|c|c|}
\hline $\begin{array}{c}\text { Employee's Demographic Characteristics (N= 116) } \\
\text { Joint Family }\end{array}$ & Frequency & Percent \\
\hline Marital Status & 30 & 25.9 \\
\hline Married & 60 & 51.7 \\
\hline Unmarried & 56 & 48.3 \\
\hline Occupational Status & 100.0 \\
\hline Private Employee & 116 & \\
\hline Monthly Family Income (in Rs.) & 59 & 50.9 \\
\hline Upto Rs.30,000 & 40 & 34.5 \\
\hline Rs.30,001 - Rs.45,000 & 17 & 14.7 \\
\hline$>$ Rs.45,001 & Mean & SD \\
\hline Descriptive Statistics & 29.03 & 3.931 \\
\hline Average Age of the Respondents & 7.02 & 2.641 \\
\hline Using Social Media (In Years) & 2.22 & 1.377 \\
\hline Average Hours Spend Time on Social Media Per Day
\end{tabular}

Table 1 indicates that all the respondents are private employees and majority of the respondents are Males, Post-Graduates, Married and hailing from nuclear families. Majority of the respondents are earning upto Rs. 30,000 as monthly family income. Descriptive statistics shows that average age of the respondents is 29.03 years. The respondents are on an average using social media for more than seven years and also use more than two hours per day.

Table 2 Factorisation of Customer Commitment in Social Media Marketing Variables

\begin{tabular}{|c|c|c|c|c|c|c|}
\hline Dimensions & Items & 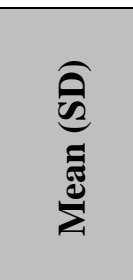 & ن & 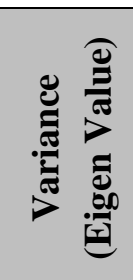 & 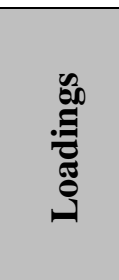 & 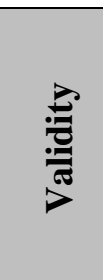 \\
\hline \multirow{7}{*}{$\begin{array}{l}\text { Information } \\
\text { Factor }\end{array}$} & $\begin{array}{c}\text { Social Media Helps to identify the } \\
\text { branded products }\end{array}$ & $\begin{array}{c}4.53 \\
(0.678)\end{array}$ & 0.769 & \multirow{7}{*}{$\begin{array}{l}42.653 \\
(4.265)\end{array}$} & 0.852 & \multirow{7}{*}{0.910} \\
\hline & $\begin{array}{c}\text { Social networking sites are } \\
\text { nurturing the new products to } \\
\text { evolve as a brand }\end{array}$ & $\begin{array}{c}4.54 \\
(0.610)\end{array}$ & 0.805 & & 0.803 & \\
\hline & $\begin{array}{c}\text { Social Media Helps to follow the } \\
\text { new arrivals about particular } \\
\text { branded products }\end{array}$ & $\begin{array}{c}4.55 \\
(0.651)\end{array}$ & 0.655 & & 0.799 & \\
\hline & \begin{tabular}{|c|}
$\begin{array}{c}\text { Social Media Usage is inducing } \\
\text { the purchase decision }\end{array}$ \\
\end{tabular} & $\begin{array}{c}4.44 \\
(0.636)\end{array}$ & 0.631 & & 0.737 & \\
\hline & $\begin{array}{c}\text { Usage about social media enhances } \\
\text { my knowledge about products }\end{array}$ & $\begin{array}{c}4.73 \\
(0.549) \\
\end{array}$ & 0.547 & & 0.725 & \\
\hline & \begin{tabular}{|c|}
$\begin{array}{c}\text { Social Media Helps to identify the } \\
\text { best products among the available } \\
\text { products }\end{array}$ \\
\end{tabular} & $\begin{array}{c}4.50 \\
(0.692)\end{array}$ & 0.622 & & 0.717 & \\
\hline & $\begin{array}{c}\text { Social Networking sites are useful } \\
\text { and interesting }\end{array}$ & $\begin{array}{c}4.57 \\
(0.563)\end{array}$ & 0.602 & & 0.692 & \\
\hline
\end{tabular}


Impact of Customer Commitment in Social Media Marketing on Purchase Decision - an Empirical Examination

\begin{tabular}{|c|c|c|c|c|c|c|}
\hline Dimensions & Items & 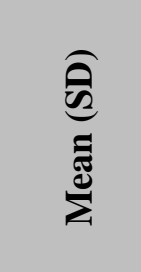 & 己 & 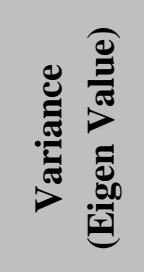 & : & 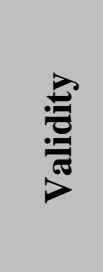 \\
\hline \multirow{3}{*}{$\begin{array}{l}\text { Experience } \\
\text { Factor }\end{array}$} & $\begin{array}{c}\text { Usage of social media provides } \\
\text { satisfaction on Purchase decision }\end{array}$ & $\begin{array}{c}3.94 \\
(0.926) \\
\end{array}$ & 0.738 & \multirow{3}{*}{$\begin{array}{l}24.183 \\
(2.418)\end{array}$} & 0.847 & \multirow{3}{*}{0.749} \\
\hline & $\begin{array}{l}\text { Usage of social media fulfill the } \\
\text { expectation of the users }\end{array}$ & $\begin{array}{c}3.99 \\
(1.017)\end{array}$ & 0.684 & & 0.766 & \\
\hline & $\begin{array}{c}\text { Social Media Enables easy } \\
\text { deliverance of opinion to other } \\
\text { users }\end{array}$ & $\begin{array}{c}4.38 \\
(0.585)\end{array}$ & 0.631 & & 0.744 & \\
\hline \multicolumn{7}{|c|}{ Total Variance $=66.836 ;$ Cronbach Alpha $=0.895$} \\
\hline \multicolumn{7}{|c|}{$\begin{array}{c}\text { KMO and Bartlett's Test } \\
\text { Kaiser-Meyer-Olkin Measure of Sampling Adequacy. }=0.910 \\
\text { (Bartlett's Test of Sphericity: Approx. Chi-Square }=643.929 ; \mathrm{df}=45 ; \text { Sig. }\end{array}$} \\
\hline
\end{tabular}

Table 2 indicates that Customer Commitment in Social Media variables with their communalities value ranging from 0.547 to 0.805 have goodness of fit for factorization KaiserMeyer-Olkin (KMO) Measure of Sampling Adequacy = 0.910 and chi-square value of 643.929 with df of 45 and P-Value of 0.000 reveals that factor analysis can be applied for factorization of 10 customer commitment in social media variables. Two dominant independent customer commitment in social media factors explaining $66.836 \%$ of total variance has been extracted out of 10 customer commitment in social media variables. Of them the most dominant factor is information Factor (IF) followed by Experience Factor (EF) in their order of dominance.

The Multiple Regression Analysis has been applied to study the significance of influence of customer commitment in social media on total social media purchase decision and the results are shown in Table 3.

Table 3 Regression Results on influence of Customer Commitment in Social Media Factors on Total Purchase Decision

\begin{tabular}{|c|c|c|c|c|c|c|c|}
\hline Dependent Variable & $\begin{array}{c}\text { Significant } \\
\text { Predictors }\end{array}$ & F-Value & $\mathbf{R}$ & $\mathbf{R}^{2}$ & $\begin{array}{c}\text { Adjusted } \\
\mathbf{R}^{2}\end{array}$ & $\begin{array}{c}\boldsymbol{\beta} \\
(\mathbf{t}-\text { Value })\end{array}$ & Sig. \\
\hline Purchase Decision & & 115.083 & 0.819 & 0.671 & 0.665 & & \\
\hline & Experience Factor & & & & & $\begin{array}{c}0.481 \\
(7.263)\end{array}$ & $<0.001 * * *$ \\
\hline & Information Factor & & & & $\begin{array}{c}0.440 \\
(6.637)\end{array}$ & $<0.001 * * *$ \\
\hline \multicolumn{7}{|c|}{ Constant with t value of 3.431 at P-Value of <0.001*** } \\
\hline
\end{tabular}

Table 3 reveals that Ordinary Least Square (OLS) Model has goodness of fit for multiple regression analysis, and the linear combination Experience Factor and Information Factor are significantly related to purchase decision $\{\mathrm{F}=115.083$, P-Value $=<0.001\}$. The multiple correlation co-efficient is 0.819 indicates that $67 \%$ of the variance of the respondents' purchase decision. From all these, it could be said that Experience Factor and Information Factor are significantly and positively influencing the purchase decision. Therefore, higher is the customer commitment in social media, higher is the purchase decision. 


\section{MAJOR FINDINGS OF THE STUDY}

1. Majority of the respondents are Males, Post-Graduates, Married and hailing from nuclear families. Majority of the respondents are earning upto Rs. 30,000 as monthly family income. Descriptive statistics shows that average age of the respondents is 29.03 years. The respondents are on an average using social media for more than seven years and also use more than two hours per day.

2. Thus, two dominant independent customer commitment in social media factors explaining $66.836 \%$ of total variance has been extracted out of 10 customer commitment in social media variables. Of them the most dominant factor is information Factor (IF) followed by Experience Factor (EF) in their order of dominance.

3. Experience Factor and Information Factor are significantly and positively influencing the purchase decision. Therefore, higher is the customer commitment in social media, higher is the purchase decision.

\section{SUGGESTIONS, IMPLICATIONS AND CONCLUSION}

Social Media helps to consumers identify the branded products, converting new products into branded products, to follow the new arrivals about particular branded products to make purchase decision among consumers. Further, social media usage enhances the knowledge of the consumer with respect new products and services and also to make screening and evaluation of alternatives to find best product or service. Social media users feel that Social Networking sites are useful, interesting and more curious to use in their day to day life. Social media helps the consumer to determine the expectations and to fulfill such expectations during their post purchase period. Consumer buying behaviour was influenced by quality, quantity, price, seller image and shopping comforts of the selected products or services. Social media helps the consumers to use experience and information to make their purchase decision with respect to products or services marketed through social media networking sites.

\section{LIMITATIONS OF THE STUDY}

Owing to time and cost constraint this primary study was restricted its samples size to 116 social media employed youth in the Chennai city of Tamil Nadu. Since, behavioural studies are dynamic due to the changes in social economic and cultural patterns in the society, findings of this study may not valid and long lasting for over a period of time. This study was adopted non-probability purposive sampling for the study. Non-probability sampling may not provide valid representation to the overall population of the study.

\section{SCOPE FOR THE FUTURE STUDIES}

This study may be conducted among student youth in near future to explore various valuable inputs to market the goods and services through social media networking sites. This study can be further extended to other geographical areas to explore difference among the peoples from different socio-economic conditions.

\section{REFERENCES}

[1] Ashley, C., \& Tuten, T, Creative strategies in social media marketing: An exploratory study of branded social content and consumer engagement. Psychology \& Marketing, 32(1), 2015, PP 15-27.

[2] Bharadwaj, A., El Sawy, O. A., Pavlou, P. A., \& Venkatraman, N, Digital business strategy: toward a next generation of insights. MIS quarterly, 2013, pp 471-482. 
Impact of Customer Commitment in Social Media Marketing on Purchase Decision - an Empirical Examination

[3] Chakravarthy, B, A new strategy framework for coping with turbulence. MIT Sloan Management Review, 38(2), 1997, 69.

[4] Chan-Olmsted, S. M., Cho, M., \& Lee, S, User perceptions of social media: A comparative study of perceived characteristics and user profiles by social media. Online journal of communication and media technologies, 3(4), 2013, pp 149-178.

[5] Chen, H., Chiang, R. H., \& Storey, V. C, Business intelligence and analytics: From big data to big impact. MIS quarterly, 36(4), 2012

[6] Cleave, E., Arku, G., Sadler, R., \& Kyeremeh, E, Place Marketing, Place Branding, and Social Media: Perspectives of Municipal Practitioners. Growth and Change, 48(4), 2017, pp 1012-1033.

[7] Constantinides, E., \& Fountain, S. J, Web 2.0: Conceptual foundations and marketing issues. Journal of direct, data and digital marketing practice, 9(3), 2008, pp 231-244.

[8] Das, B., \& Sahoo, J. S, Social networking sites-a critical analysis of its impact on personal and social life. International Journal of Business and Social Science, 2(14), 2011, pp 222228.

[9] Dey, L., Haque, S. M., Khurdiya, A., \& Shroff, G. Acquiring competitive intelligence from social media. In Proceedings of the 2011 joint workshop on multilingual OCR and analytics for noisy unstructured text data $A C M, 2011, \mathrm{p} 3$

[10] Donner, J, Research approaches to mobile use in the developing world: A review of the literature. The information society, 24(3), 2008, pp 140-159.

[11] Ha, H. Y, The effects of consumer risk perception on pre-purchase information in online auctions: Brand, word-of-mouth, and customized information. Journal of ComputerMediated Communication, 8(1), JCMC813, 2002

[12] Kaplan, R. S., Davenport, T. H., Robert, N. P. D. K. S., Kaplan, R. S., \& Norton, D. P, The strategy-focused organization: How balanced scorecard companies thrive in the new business environment. Harvard Business Press, 2001

[13] Keller, K. L., Parameswaran, M. G., \& Jacob, I, Strategic brand management: Building, measuring, and managing brand equity. Pearson Education India, 2011

[14] Kotler, P, Marketing management: A south Asian perspective. Pearson Education India, 2009

[15] Mas-Tur, A., Tur-Porcar, A., \& Llorca, A, Social media marketing for adolescents. Psychology \& Marketing, 33(12), 2016, pp 1119-1125.

[16] Munro, J., \& Richards, B, The digital challenge. Destination brands: Managing place reputation, 2011, pp 141-154.

[17] Norris, P, Digital divide: Civic engagement, information poverty, and the Internet worldwide. Cambridge University Press, 2001

[18] Rheingold, H, Using participatory media and public voice to encourage civic engagement. Civic life online: Learning how digital media can engage youth, 2008, pp 97-118.

[19] Teece, D. J., Pisano, G., \& Shuen, A, Dynamic capabilities and strategic management. Strategic management journal, 18(7), 1997, pp 509-533.

[20] Tidd, J., \& Bessant, J. R, Managing innovation: integrating technological, market and organizational change. John Wiley \& Sons, 2018

[21] Yazdanifard, R., Obeidy, W. K., Yusoff, W. F. W., \& Babaei, H. R. (2011). Social networks and microblogging; the emerging marketing trends \& tools of the twenty-first century. The Proceedings of 2011 International Conference on Computer Communication and Management, Vol. 5, 2011, pp. 577-581 